\title{
The Interface between Technological Protection Measures and the Exemptions to Copyright under Article 6 Paragraph 4 of the Infosoc Directive and Section 1201 of the Digital Millennium Copyright Act, with Particular Respect to the Implementation of Article 6 Paragraph 4 in the National Laws of Greece, UK, and Norway
}

\author{
Victoria Banti-Markouti \\ Kapodistrian University of Athens, Faculty of Law, \\ Athens, Greece \\ victoriabanti@yahoo.com
}

\begin{abstract}
The freedom of use of knowledge products is the main characteristic of the digital environment which challenges traditional copyright law. The development and diffusion of digital technology permits unauthorised creation of unlimited and costless copies. The copyright industries are responding by using anti-circumvention measures such as encryption technologies. This paper focuses mostly on the interface between the technological protection measures and the exemptions to copyright under the European Copyright Directive, article 6(4) and the Digital Millennium Copyright Act, section 1201. The policy reasons and objectives of the provisions will be presented. Then their impact on the rights of the users and the effectiveness of the provisions will be assessed. Finally specific proposals are being suggested for a balance between the rights of the copyright holders and the public in the digital environment. The different implementation methods of article 6(4) by the member states are also criticized.
\end{abstract}

Key words: Digital Millennium Copyright Act, Information Society Directive, anticircumvention, technological protection measures, rights of users

\section{Introduction: Digital Technology and Copyright Law}

As Louis Brandeis in International News Service v. Associated Press (1918) put it in the beginning of the previous century: 'The general rule of law is, that the noblest of human productions knowledge, truths ascertained, conceptions and ideas become, after voluntary communication to

Material published as part of this publication, either on-line or in print, is copyrighted by the Informing Science Institute. Permission to make digital or paper copy of part or all of these works for personal or classroom use is granted without fee provided that the copies are not made or distributed for profit or commercial advantage AND that copies 1) bear this notice in full and 2) give the full citation on the first page. It is permissible to abstract these works so long as credit is given. To copy in all other cases or to republish or to post on a server or to redistribute to lists requires specific permission and payment of a fee. Contact Publisher@InformingScience.org to request redistribution permission. others, free as the air to common use'. This freedom of use of knowledge products is the main characteristic of the new digital environment which challenges traditional copyright law. Indeed, the development and diffusion of digital technology permits unauthorised creation of unlimited and costless copies and worldwide distribution of protected works. The copyright industries are responding by using anti-circumvention 
Interface between Technological Protection Measures and the Exemptions to Copyright

measures such as encryption technologies.

In such an environment there is need for rethinking of the traditional copyright law. The new opportunities offered by the Information Society to enjoy and exploit protected works call for adjustment of the manner that copyright is protected. This does not mean that copyright should be abolished or restricted. But it is important that the policy makers make adjustments in the light of all interests concerned.

Technological copyright protection measures, which will be described in the first chapter of this paper, have been put into force and are legally protected by the European Directive on the harmonisation of certain aspects of Copyright in the Information Society and by the Digital Millennium Copyright Act in the US.

In this paper I shall focus mostly on the interface between the technological protection measures and the exemptions to copyright under the European Copyright Directive, article 6(4) and the Digital Millennium Copyright Act, section 1201. In my comparative critical review I shall try to explore not only the legal but also the general economic, social and political reasons that led to these provisions. I will not take into account any case law. The reason for this is that there does not appear to be any case law directly referring to article 6(4) of the Infosoc Directive.

The choice of this particular topic was made since much discussion has been carried out in most of the European member states about the implementation of article 6(4) and its effects to the rights of the users. In addition, the US system is presented as a contrast to the European. I will make a short reference to the Enforcement Directive which was adopted in late May 2004. I will not refer to it due to space considerations.

Furthermore, I shall examine the harmonisation issue of the Copyright Directive and its implementation in Greece, UK and Norway. Not much research has yet been done on the harmonisation issue in a European level. The implementation in the member states is still in different stages. Greece was one of the very first countries to implement, the UK implementation was completed after long proceedings just by the end of 2003 and Norway is still in the process of implementation. For my comparative analysis the use of different legal sources from various jurisdictions is needed. Therefore, I try to overcome the difficulties in determining what the law is in different jurisdictions and making valid comparisons given the different legal systems.

As concerns the methodology that is being followed, this research is engaged both in normative assessment and legal dogmatics. I shall try to critically examine the law in order to arrive at my own suggestions for improvement. Thus, I try at the same time to make my analysis both de lege lata and de lege ferenda. For this purpose the policy reasons and objectives of the provisions 6(4) of the Copyright Directive and the section 1201 of the DMCA will be presented. Then their impact on the rights of the users and the effectiveness of the provisions will be assessed. Finally, I shall present my proposals for a balance between the rights of the copyright holders and the public in the digital environment. I shall also criticise the different implementation methods of article $6(4)$ by the member states.

This structure has the design of a pyramid. At the very first and narrow level is article 11 of the WIPO Copyright Treaty which was the primary formal catalyst for the EU and US provisions that are the main focus of this paper. The second level concerns the implementation of that article in the EU and the US through article 6(4) of the Infosoc Directive and section 1201 of the Digital Millennium Copyright Act respectively. Then at the last level the implementation of the article 6(4) in three of the member states takes place. The main body of analysis in this paper is found in chapters 3 and 4 . However, chapters 1 and 2 are needed introduction to develop a further analysis and reach conclusions. 
This architecture was chosen because it serves best to reach the main argument of this thesis. This argument is that the way article 11 of the WIPO Treaty is implemented through article 6(4), has the objective to shift the balance of protection more towards the rights of the copyright industry thereby jeopardising the larger public interest

\section{The Need for Protection of Intellectual Property Rights in the Digital Environment}

In Lessig's words, the Internet seems to be the worst of both worlds for copyright owners: both a place where the ability to copy and distribute cannot be better and where the protection of the law could not be worse (Lessig, 1999). Alternatively, as it has been claimed by John Perry Barlow, founder of the Electronic Frontier Foundation, that in the contact of the Internet 'everything you always knew about intellectual property is wrong'. (Hugenholtz, 1999)

Trying to look at the validity of these statements in this chapter I shall briefly examine the new conditions of the digital environment, the methods used for the protection of copyright and the first steps for the creation of an international legal framework through the WIPO Treaties in 1996.

\section{Copyright Infringement through Digital Technology: Copying and Distribution}

The practical test of Petersen in University London Press Ltd v University Tutorial Press Ltd, (1916) 2 Ch 601 at 610 per Petersen J., that what is worth copying is prima facie worth protecting is demonstrated perhaps nowhere so strikingly as in the digital environment. The Internet is sometimes described as 'global copying machine' with millions of anonymous pirates pushing the buttons. (Hugenholtz, 1999)

Even so, discovering copyright infringement is relatively easy through search engines widely available.

There are numerous ways to misappropriate a creation on the Internet such as copying a work without permission, reproduce the style of the original creation deliberately leading others to believe that the work is that of the original creator, fail to give credit for a reproduction or inaccurately attribute credit in the case of a distorted work. It is indeed possible to access published works and reproduce large quantities of this material with some basic keystrokes with very little capital outlay when compared to the demands of traditional methods of reproduction (Lim, 2002).

As an example we could mention a 1998 Price Water House Report commissioned by the Business Software Alliance estimated that over 40 per cent of European Business Software was illegally copied (O'Sullivan, 2002). While, the 1999 Global Software Piracy Report claims that this rate stood at 36 per cent (O'Sullivan, 2002).

Furthermore, the peer-to-peer technology (Bowrey \& Rimmer, 2002) revolves around a question of law's service to economics, old commerce and e-commerce. As Larry Lessig explains, the internet conflicts with the control of the Hollywood industry over music, films and other forms of intellectual property and therefore industry tries to win this battle by using strong legal means (Bowrey \& Rimmer, 2002).

\section{The Advancement of Technology and the Progress of Law: Copyright Protection Measures}

'The answer to the machine is the machine' (Clark, 1996, p.139-146). By this sentence Clarkes Clark stated that technology can be used to safeguard the intellectual property rights threatened by the same technology (Dusollier, 1999). The practice has proved the validity of this statement 
Interface between Technological Protection Measures and the Exemptions to Copyright

.The technological development has led to the use of technological measures by the copyright owners in order to prohibit the infringement of their rights or restrict the illegal actions. Indeed, technological protection measures have been characterised as 'powerful new weapons in the copyright arsenal' (Hugenholtz, 1999).

In a more general definition given by $\mathrm{M}$. Fallenbock, technological protection measures refer to techniques that permit providers of information in digital form to regulate access to and/or use of their products. These measures can perform a vast range of functions. They can simply gather information about every use of a digitally encoded work. They can also limit or altogether prevent its use (Fallenbock, 2002/2003).

A number of technological devices have been developed in order to protect the rights of the copyright holders in the digital environment. Such measures are the anti-copying devices, the control of access by encryption, watermarking or fingerprinting technique. In order to understand the exact use of technological measures we shall briefly examine two of the most common methods: watermarking and encryption.

\section{Watermarking}

Digital watermarking is the process whereby certain digital information is integrated into the actual work in a way that is not humanly discernible but capable of being perceived by special reading devices or software (Fallenbock, 2002/2003).

It is a method by which an identifier can be permanently attached to a given content such as the content of DVDs. It also affixes a coded and usually invisible label containing copyright management information to a digital object on the Internet. Watermarking is especially useful for the detection of piracy as it is capable of detecting any alteration of the original object (de Kroon, 2000).

As an example we could refer to a certain use of 'watermark' which was made by the Secure Digital Music Initiative (SDMI), a global coalition of more than 150 companies whose aim is to protect music in all existing and emerging digital formats and through all delivery channels. According to that plan in due course every recorded music track will have a 'watermark' embedded in it, a thread of audio data that identifies it. Consumers then would be able to download music with the 'watermark' software from websites and save it on their computers. A SDMI music file, upon being downloaded to a listening device, would look for SDMI security software on the device. A SDMI compliant music player would likewise look for SDMI security software (Stamatoudi \& Torremans, 2000).

\section{Encryption}

Cryptography is the art of using mathematical codes and algorithms to scramble text so that it appears random to all statistical tests and can, therefore only be read by specified individuals (Lim, 2002). Encryption usually refers to the process of scrambling or encoding digital information so that it is only readable to those who have the tools to decrypt it. (Hugenholtz, 1999) By using encryption commercial information producers can prevent the unauthorised access to their information services or products. Access is allowed only to those in possession of the right key. (Fallenbock, 2002/2003)

Under the DMCA the copyrighted work once encrypted is housed in a 'protective cocoon' that does not allow for fair use in the ordinary sense where decryption is required to enable access. This matter has led to the creation of an ancillary set of legal relations to do with the encryption process as a separate entity (Bowrey \& Rimmer, 2002), while many things have been written about the 'fair use' defence and the technical difficulties that have arisen from the use of encryption. 
Meanwhile a number of other protection systems for music files have been developed independently and have been adopted by various recording companies. For example Liquid Audio, have competing technologies which are used in online delivery and payment systems for music.

A good example of a currently operating system is i-tunes by apple. In its first year, i-tunes sold more than 70 million songs. Similar activities are currently made by Microsoft WindowsMedia Player and Real Networks Music Store.

\section{Creating the International Legal Framework: the WIPO Treaties 1996, article 11}

In December 1996 the WIPO Copyright Treaty and the WIPO Performances and Phonograms Treaty were agreed in Geneva. The beneficiaries are authors of literary and artistic works and the basic principles are compliance with the Berne Convention, national treatment and guarantee of specified additional rights of distribution, certain rental rights and an extended right of communication to the public (Sterling, 2003).

While the WIPO Copyright Treaty contains no specific provisions as to what constitutes infringement, there are provisions concerning remedies against circumvention of technological prevention measures in article 11 (Koelman \& Helberger, 2000). This article is the first provision directly aimed at the actual circumvention of technological copyright protection measures. Apparently, the final wording of the provision is the result of successful lobbying by producers of consumer electronics. Also, the WIPO Performances and Phonograms Treaty in article 18 refers to obligations concerning technological measures.

Further, in September 1999, WIPO put forward a Digital Agenda addressing abuses of Intellectual Property rights on the internet and specifically calling on its member states to examine the feasibility of creating agreed procedures and forms for worldwide licensing of intellectual property rights in digital form (Stamatoudi \& Torremans, 2000).

Before examining the EU and US relative provisions it is worth mentioning that developing countries will come under pressure, for instance in the context of bilateral agreements with developed countries, to accede to the WIPO Copyright Treaty or even to adopt stricter prohibitions against circumvention of technological protection systems and effectively thereby reducing the scope of traditional 'fair use' agenda (Commission on Intellectual Property Rights, 2002, p. 106)

\section{The Anticircumvention Provisions from Both Sides of the Atlantic}

In this chapter I shall pass from the first level of the pyramid structure to the second one. Therefore, I shall discuss the implementation of the WIPO Treaties in the US and the European Union. In particular I shall examine briefly the Digital Millennium Copyright Act while more emphasis in the analysis will be given to the European Directive for the 2001/19/EC on the harmonisation of certain aspects of copyright and related rights in the information society. A comparison of the two legislative measures will be conducted in the fourth chapter.

\section{The Digital Millennium Copyright Act}

The underlying goal of the DMCA is to bring US Copyright law 'squarely into the digital age'. This law proposes to make digital networks safe places to disseminate and exploit copyrighted materials by creating the legal platform for launching the global digital on-line marketplace for copyrighted works. It also tries to 'make available via the Internet the music, movies, software, and literary works that are the fruit of American creative genius' (Fallenbock, 2002/2003). 
Interface between Technological Protection Measures and the Exemptions to Copyright

In this paper I shall focus on the provision of section 1201 which refers to the exceptions to copyright.

\section{Exemptions from the anticircumvention provision}

The DMCA offers exemption provisions in section 1201. These exemptions have different thresholds for qualification and apply to different subsections of section 1201 . The result is a highly complex system (Fallenbock, 2002/2003).

Here, the most important exemptions shall be examined. Section 1201(d) provides an exemption for non profit libraries, archives and educational institutions to gain access to a commercially exploited copyrighted work. However, the exemption does not permit the trafficking of the circumventing devices necessary to effectuate the permitted circumvention.

Further, section 1201(e) permits circumvention and the development of circumvention devices for any lawfully authorised investigative, protective or intelligence activity by a federal, state or local government employee, or a person under contract to federal state, or local government.

It is interesting to see the provision for protection of minors. Section 1201 (h) allows the development of circumvention components that would permit a parent to access a restricted website visited by his child.

In addition, a significant exemption is also the personal privacy exemption in section 1201 (j) which permits circumvention when the technological measure is capable of collecting or disseminating personally identifiable information about the online activities of a natural person.

At this point it is useful to state my agreement with Dr. Bygrave who emphasize the surveillance dangers to the acceptable operation of digital rights management systems (DRMS). As they have stated the surveillance potential may not only weaken the privacy of information consumers but also function as a form for control. In the worst scenario this control could develop as a kind of digital 'Panopticon'. They also stress the potential implications of this for the vitality of pluralist, democratic society (Bygrave, 2003).

Also, one of the most important exemptions for fair use is the reverse engineering exemption in section 1201 (f). This exemption permits circumvention by a person who has lawfully obtained a right to use a copy of computer program for the sole purpose of identifying and analysing elements of the program necessary to achieve interoperability with other programs to the extent that such acts are permitted under copyright law.

Additionally, section 1201 (g) includes an exemption for encryption research which permits circumvention of access control measures, and the development of the technological means to do so, in order to identify flaws and vulnerabilities of encryption technologies.

A general fair use-like exemption to the right to control access did not appear in the DMCA's early drafts. In the House Committee on Commerce such a provision was proposed, but eventually rejected by the majority (Koelman \& Helberger, 2000).

However, the lack of a 'legitimate fair use' exemption in the DMCA is already preventing users of works from exercising their rights. Millions of copyprotected CDs are in circulation around the world. It is illegal to circumvent the protection to make a personal copy in another format or to collect songs from different artists together in a mix CD or tape (Brown \& Bohm, n.d., p.16).

Fair use permitted duplication of certain portions for appropriate purposes. Duplication is now denied, regardless of the amount taken or reason for the taking unless the user falls within one of the special status exemptions (Bowrey \& Rimmer, 2002). 


\section{The Directive 2001/29/EC on the Harmonisation of Certain Aspects of Copyright and Related Rights in the Information Society}

The Copyright Directive was adopted on the $9^{\text {th }}$ of April, 2001 and had to be implemented by the member states by the $22^{\text {nd }}$ of December, 2002. It aims to bring greater harmonisation to European copyright law in the new digital environment and implements in the European Union the two WIPO to raise the standard. 'If in Geneva international lawmakers, in their wisdom, agreed upon a rather loosely formulated provision obliging countries to 'provide adequate legal protection and effective legal remedies against the circumvention of effective technological measures' (article 11 of the WCT), the EC would carve a precise anti-circumvention rule in stone.' Treaties of 1996.

At this point, it is worth noting the view of Bernt Hugenholtz with which I fully agree. As he pointedly describes (Hugenholtz, 2000) the original aim of the Directive was, to bring the laws on copyright and related rights in the European Union in line with the WIPO 'Internet Treaties'.

The importance of this kind of 'rule carving' for the industry can be seen by the high percentage of their participation during the drafting procedures. Although many directives claim the title of the 'Most Lobbied', the number of interests engaged in active lobbying in this proposal was striking. They included representatives of the music, film, publishing IT hardware and software, consumer-electronics and telecommunication industries, collecting societies and a wide assortment of author, artist and consumer groups (Hart, 2002). All this participation underlines the importance of the directive for the copyright industry and the public and the pressure posed by the industry in order to reassure their economic rights which derive from the copyright exploitation.

This paper is focused mostly on article 6 (4) which has been correctly characterised as 'a highly unusual and unclear provision and very much the creature of political compromise' (Hart, 2002). As this paper will make clear such characterisation is apt.

\section{Background}

The Commission in its proposal for a directive on certain aspects of copyright and related rights in the information society addressed the matter of legal protection of electronic management and protection systems. In particular in its explanatory memorandum on December 10, 1997 the Commission expressed the fear that a fragmented approach at member-states' level with respect to the legislation that should flank the technical protection and identification schemes used by holders of copyright and related rights would not only entail difficulties for the protection of copyright and related rights, but also adversely affect the proper functioning of the internal market (Fallenbock, 2002/2003).

The European Parliament voted large amendments to the provision of article 6 to the effect of a stronger protection of technological measures presented in its proposal at the beginning of 1999 . But, the European Commissioner Mario Monti informed the Parliament that the Commission would not accept all the amendments (Dusollier, 1999).

The article 6 (4): obligations to the member states:

Article 6 reads:

Obligations as to technological measures

1. Member States shall provide adequate legal protection against the circumvention of any effective technological measures, which the person concerned carries out in the knowledge, or with reasonable grounds to know, that he or she is pursuing that objective. 
Interface between Technological Protection Measures and the Exemptions to Copyright

2. Member States shall provide adequate legal protection against the manufacture, import, distribution, sale, rental, advertisement for sale or rental, or possession for commercial purposes of devices, products or components or the provision of services which:

(a) are promoted, advertised or marketed for the purpose of circumvention of, or

(b) have only a limited commercially significant purpose or use other than to circumvent, or

(c) are primarily designed, produced, adapted or performed for the purpose of enabling or facilitating the circumvention of,

any effective technological measures.

3. For the purposes of this Directive, the expression "technological measures" means any technology, device or component that, in the normal course of its operation, is designed to prevent or restrict acts, in respect of works or other subject-matter, which are not authorised by the rightholder of any copyright or any right related to copyright as provided for by law or the sui generis right provided for in Chapter III of Directive 96/9/EC. Technological measures shall be deemed "effective" where the use of a protected work or other subject-matter is controlled by the rightholders through application of an access control or protection process, such as encryption, scrambling or other transformation of the work or other subject-matter or a copy control mechanism, which achieves the protection objective.

4. Notwithstanding the legal protection provided for in paragraph 1, in the absence of voluntary measures taken by rightholders, including agreements between rightholders and other parties concerned, Member States shall take appropriate measures to ensure that rightholders make available to the beneficiary of an exception or limitation provided for in national law in accordance with Article 5(2)(a), (2)(c), (2)(d), (2)(e), (3)(a), (3)(b) or (3)(e) the means of benefiting from that exception or limitation, to the extent necessary to benefit from that exception or limitation and where that beneficiary has legal access to the protected work or subject-matter concerned.

A Member State may also take such measures in respect of a beneficiary of an exception or limitation provided for in accordance with Article 5(2)(b), unless reproduction for private use has already been made possible by rightholders to the extent necessary to benefit from the exception or limitation concerned and in accordance with the provisions of Article 5(2)(b) and (5), without preventing rightholders from adopting adequate measures regarding the number of reproductions in accordance with these provisions. The technological measures applied voluntarily by rightholders, including those applied in implementation of voluntary agreements, and technological measures applied in implementation of the measures taken by Member States, shall enjoy the legal protection provided for in paragraph 1.

The provisions of the first and second subparagraphs shall not apply to works or other subject-matter made available to the public on agreed contractual terms in such a way that members of the public may access them from a place and at a time individually chosen by them.

When this Article is applied in the context of Directives 92/100/EEC and 96/9/EC, this paragraph shall apply mutatis mutandis.

\section{General Presentation of Article 6}

Article 6 is placed in the middle of the directive which contains twelve articles. It is placed right after the article 5 which refers to the exceptions and limitations of copyright. Article 7 about obligations concerning rights-management information and article 6 constitute chapter III on the protection of technological measures and rights management information. 
Article 6(1) refers to the undefined 'adequate legal protection' that member states shall provide against the circumvention of any effective technological legal measures. The second paragraph refers to 'adequate legal protection' by the states against secondary infringement such as distribution, sale, rental of devices which facilitate circumvention.

Then, paragraph 3 gives a definition of 'technological measures' and speaks also about their effectiveness. Comments on this definition are made further in this paper. Lastly, paragraph 4, which is the main focus of our interest, opens up for market mechanisms, introduces flexibility and makes an attempt to alleviate problems that paragraphs 1 and 2 could cause.

\section{Presentation of Article 6(4) and its Role in Relation to the Other Paragraphs of Article 6}

The Directive in article 6(4) recognises the importance of private agreements and noninstitutional mechanisms of settling disputes between the right holders and the users such as mediation. The lack of sufficient legal framework in the digital environment permits mostly voluntary arrangements among users rather than state intervention. Of course this does not suggest that legal means cannot be put into force in the digital arena. Courts of justice have solved many important disputes such as those discussed in sections 2.1.1 and 2.2.3 of this paper.

Paragraph 4 comes after the definition of 'effective technological measures' in paragraph 3 which can be used by copyright holders for the protection of their rights. It is also connected to paragraph 1 and it refers to situations when voluntary measures taken by rightholders are absent. A problematic area of article 6(4) is the fact that it solely refers to paragraph 1 and not paragraph 2 of the same article. As a consequence, the user cannot provide himself or others with a circumventing device to facilitate the circumvention of a technological protection measure so as to have access to the material that he or others can legally copy.

It is noteworthy that in the proposal for the Infosoc Directive 98/C 108/03 the paragraphs 3 and 4 are not included. While, in the amended proposal C 180, 25/06/1999 although the third paragraph was added, the forth paragraph was still not included. Paragraph 4 appears for the first time in the Common Position (EC) No 48/2000. Then, in the Communication from the Commission COD $97 / 0359$, the Commission takes the view that 'the solutions found in the Council to the difficult issues posed by Article 6 and in particular its relationship to Article 5 represent remarkable progress in the effort to ensure effective and adequate protection of rightholders whilst at the same time not neglecting the legitimate interests of beneficiaries of exceptions. It can therefore support it fully'.

If from this statement we conclude that the Commission's intention was to keep a balance between these two conflicting rights this is not necessarily apparent from the wording of this article. Particular focus on uncertainties and ambiguities of the statutory language will be given in the next paragraph. As it will be pointed out subsequently, this goal of the Commission to safeguard the rights of both sides is not being fulfilled. The position of the right holder is being extended at the expense of the users. Article 6(4) does not go enough at redressing its rebalance.

In fact, article 6 (4) tries to give a solution to the situation where the beneficiary of a copyright exception cannot make use of his/her legal right since the material that he tries to access is protected by a technological protection measure. These exemptions refer to reprographic copying, copying by libraries and ephemeral recordings by broadcasting organisations, copying for teaching or scientific research, copying for people with disability, for purposes of public security or reporting of administrative, parliamentary or judiciary proceedings.

All these exemptions are described in article 5(2) a, b, c, d, e, and 5(3) a, b, e. They may also include the private use exemption, but must allow rightholders to restrict the number of private cop- 
Interface between Technological Protection Measures and the Exemptions to Copyright

ies so made (Brown \& Bohm, n.d., p.10). Indeed this restriction can be seen in practice through the UK implementation whereas self-service copying is now permitted only for non-commercial purposes and according to the guidelines of the Royal Society of Medicine, (Royal Society of Medicine, 2003) only one article in a journal can be copied and only one chapter of a book or no more that 5 per cent of the total work. Before the implementation of the Directive the most wellknown example of private copying was the rule of thumb that 10 per cent of a book may be copied. (Bently \& Sherman, 2001, p.175)

Also, several of these exemptions require fair compensation. Nevertheless, recital 35 makes clear that one of the factors that must be taken into account in setting the level of such compensation is the use of technical measures. The same wording is followed by article 5 (2) (b) and recital 52. It is argued that it is likely that fair compensation levels will be reduced as the use of technical measures increases. (Brown \& Bohm, n.d., p. 10).

In the absence of such measures taken by the rightholders, member states shall take appropriate measures to ensure the right of the beneficiaries according to the exemptions. Indeed, by this article the Commission leaves this area more open to the market initiatives.

Furthermore, article 6 (4) (2) allows the extension of the rights of the rightholders for the disadvantage of the users. Then, inevitably, the question that arises is whether the 'fair use/fair dealing' exemption has any future in the digital arena. Member states may take measures for private copying but are not obliged to do so. Accordingly, if a TV station prevents by technological protection measures the private recording of a programme then the users are deprived of their right to private copy.

In addition, the defence of fair dealing for criticism or review has been made available only when the material taken has been made public with the copyright owner's authority. Previously, the private nature of the material was only a factor which might weigh against the dealing being fair. (Brown \& Bohm, n.d., p,63).

\section{Analysis of article 6(4) with particular focus on uncertainties and ambiguities}

There is not a detailed definition of the term 'appropriate measures' in the Directive. The Commission avoids giving any guidelines and perhaps one of its reasons is the different legal, political and social reality of the member states. Hence, there is much room for the states to create and apply their own appropriate measures. Such definitions of appropriate measures are given by the member states during the implementation procedure. Respectively, we shall examine the relative provisions of the UK, Greek and Norwegian implementation in the forth chapter.

Nevertheless there are many open questions about the meaning of 'appropriate measures'. Perhaps a member-state could actually legislate to oblige a rightholder to adapt their technical protection device to permit an exemption to be exercised. Or governments could discuss the access and copying issues with the relevant rightholder. Another hypothesis could be that rightholders might be sued by consumer groups for non-compliance with the mandatory obligation of article 6 (1) (Hart, 2002)

In addition, article 6(4) (4) excludes the works made available through on demand services. The definition of these services is rather broad and is given by both article 6 (4) (4) and recitals 25 and 53. In particular on demand services are 'agreed contractual terms in such a way that members of the public may access them from a place and at a time individually chosen by them.' It is worth mentioning that the implementation of the Directive in the UK did not include 'copyright works made available by an on-demand service' (Hart, 2002) along with performance, database and publication rights. On the other hand, according to the Norwegian proposal for implementation 
on-demand service is defined as a service where the user can choose the time and place to access it.

All these ambiguities have led to the characterisation of the Directive as 'a badly drafted, compromise-ridden, ambiguous piece of legislation' (Hugenholtz, 2000). As Hugenholtz further elaborates although the main goal of the directive according to its preamble is to increase legal certainty it creates new grey areas by the use of vague statutory language.

Another important difficulty created by the formulation of this article is the fair use of copyright by disabled persons. For example will a blind person who asks to purchase a published work via the net and then have that work turned into Braille be prevented since she can access that webpage at time and place individually chosen by her? Given the exact wording of this provision the answer to that is yes (Hart, 2002).

Finally, the provision of article 6(4) is indeed very complicated and although some direction is provided in recitals 51, 52, 53 it still seems difficult to draw a clear picture of its scope. Accordingly, member-states have struggled to establish legal mechanisms to ensure workable application in practice (Braun, 2003) and this struggle will be presented in the following chapter of this paper.

\section{The Problem of Harmonisation of National Laws: The Implementation of the EC Directive in the Member-States}

Harmonisation is a major issue stressed by the Commission in the preamble of the Directive. As it is stated in recital 4 'a harmonised legal framework on copyright and related rights, through increased certainty and while providing a high level of protection of intellectual property, will foster substantial invention in creativity and innovation [...] led in turn to growth and increased competitiveness of European industry'.

In order to understand the significance of the harmonisation issue I shall first examine the bigger picture. One of the main objectives of the European Union is the creation of a common market. The common market is defined in article 8a of the EC Treaty as 'an area without internal frontiers in which free movement of goods, persons, services and capital is ensured'.

Since the second half of the 80's the European Union has focused on the need to compete in the arena of global economy against NAFTA and ASEAN trade blocs or US and Japan. Indeed, the EU wanted to boost the credibility of the internal market programme and to compete in the arena of international markets (Tsoukalis, 1997). Moreover, in March 2000 the European Council set a new objective for the Union for the next decade: to become the most competitive and dynamic knowledge-based economy in the world (European Commission Report, 2000, p. 5).

Without harmonisation legislation activities at national level might result in significant differences and thereby in restrictions on the free movement of intellectual property services and products leading to a refragmentation of the internal market and legislative inconsistency (recital 6). To that end those national provisions which vary considerably from one member state to another hindering the smooth functioning of the internal market and the proper development of the information society in Europe should be adjusted (recital 7). Nevertheless, my view (that derives also from the recitals) is that harmonisation in itself is not a sufficient reason to justify changes which are inconsistent with other regulation.

In order to facilitate the realisation of the goals of the exemptions and limitations described in the Directive (art.6 par.4 (a), art.5 par.2 (a), (b), (c), (d), (e) and par.3 (a), (b), (e)) the member states should promote the taking of voluntary measures such as the application of agreements among the right-owners and third parties. Otherwise, the member states should take the relevant action so as 
Interface between Technological Protection Measures and the Exemptions to Copyright

to facilitate the beneficiaries of the exemptions or the limitations. This action is described by the Directive as 'appropriate measures'.

In particular, as refers to technological measures, recital 52 states that in order to prevent abuse of voluntary measures, any technological measures applied in their implementation should enjoy legal protection. Additionally, recital 53 was added after the proposed amendment of the European Parliament. (Kallinikou, 2001) 'The protection of technological measures should ensure a secure environment for the provision of interactive on demand services, in such a way that members of the public may access works from a place and time individually chosen by them'.

Furthermore, suggestions for the harmonisation issue are presented in recital 54 whereas 'compatibility and interoperability of the different systems should be encouraged' as well as 'the development of global systems'.

In articles 6 par.1, 2, 4 and article 7,1 much room to manoeuvre is given to member states in order to implement the community legislation to their national laws. This is actually the legal status of a directive. Directives are legally binding only in terms of the result. The member states should use their own means according to the reality of their interior to reach the main goal of the Directives (Skandamis, 1997). The amount of such discretion is quite wide in article 6(4).

The statutory language that is being used in article 6 can be characterised as vague. 'Member states shall provide adequate legal protection' (art.6 par.1,2, art.7 par.1) , 'member states shall take appropriate measures' (art. 6 par.1,2). No exact definition for 'legal protection' or 'appropriate measures' is given by the Directive. Indeed, the member states should implement the Directive according to their point of view, existing legislation and special needs.

Another interesting point when it comes to the harmonisation of European markets and the exemptions for teaching and scientific research is that there is very little inter-state trade which flows from the use of photocopiers in study and research as the Commission used to acknowledge (Cornish \& Llewelyn, 2003. p. 511). Therefore, the justification for the directive that there will be distortion of the EU markets without harmonisation and strong exemptions cannot be considered valid and the exemption to reproduction for scientific purposes is extremely restrictive.

It is also worth mentioning that the new Enforcement Directive of intellectual property rights has the objective to enforce copyrights, patents, and trademarks in Europe, and create more difficulties for those who tamper with technical anticopying mechanisms. The directive has been welcomed by the music and film industries (Anderson, n.d.)

In order to analyse the harmonisation issue from a practical perspective it is interesting to examine how the UK, Greece and Norway follow the implementation procedure of the anticircumvention provision of article 6(4) of the Infosoc Directive in their national jurisdictions.

Although the Directive allowed 19 months for its implementation, only Greece and Denmark met this deadline. The implementation procedure in the three member states is in three different stages. Greece has implemented the directive in 2002 and the implementation procedure followed by the Greek parliament was perhaps the simplest OF the rest of the member states. In the UK, the implementation which ended only a few months ago has been a highly controversial issue which caused a wide national debate. Finally, the implementation procedure is currently taking place in Norway (spring 2004).

\section{Greece}

The implementation of the directive 2001/29/EC on the harmonisation of certain aspects of copyright in Greece was carried out pursuant to article 81 of the law 3057/202. This law which entered 
into force on 10.10.2002 amended the law 2121/1993 (Iglezakis, 2003) which is known as 'the intellectual property law'.

The implementation of the Directive in Greece was perhaps the easiest implementation made by any other member-state. The Minister of Culture, Evangelos Venizelos, announced to the Parliament that the proposed provision of section 81 of the Bill essentially consisted of a translation of the Directive to be implemented, thereby implying that there really was no sense in extensively debating it. Section 81 was eventually unanimously voted into law in the form proposed by the Government (Maroulis, n.d., p. 2).

I contest this uncritical acceptance of such a controversial directive in general and of the crucial provision of article 6(4) in particular. In my view the Greek Parliament acted without taking full consideration of the matter and its implications for the public interest. I posit that this lack of debate is attributed to the general ignorance of the wider part of the public and the parliamentarians about the digital environment in general. However, the few voices against this uncritical implementation will be presented in the following chapter.

In supplementing my arguments I note that no distinction between off-line and on-line copyright protection is made in the Greek copyright law, since the provisions, which introduced rules of copyright protection in the information society are integrated into the law on the authors' rights and not in some specific legislation (Iglezakis, 2003). Internet is not as widely spread in Greece as in other member states. According to OECD Room Document "The 'Digital Divide' in Greece" (n.d.) the percentage of Internet users surpassed 10\% of the population (over 15 years old) during the first semester of 2001 while it is expected to exceed $12 \%$ by the end of the year (international projections placed Greece at this level by the end of 2004).

It is noteworthy that only fifty out of the three hundred Greek parliamentarians had an e-mail address in 1998 while the vast majority of the parliamentarians in all the other member states had email addresses.

Therefore, the legislators don't have social incentives to make a distinction between on-line and off-line copyright protection. However, it would be commendable that the law foresees the inevitable social and technological evolution and is prepared to confront potential difficulties.

The implementation of article 6 (4) of the Directive by the Greek law (article 66A (5)) gives the possibility for right holders (IT \& Public Policy, 1998) and beneficiaries of exceptions to request voluntarily the assistance of one or more mediators selected from a list drawn up by the 'Copyright Organisation'.

Further, if one of the parties does not accept the recommendations made by the mediators within one month the dispute will be settled by the Court of Appeal without any further possibility to appeal (Braun, 2003).

However, the security of justice would be stronger if there was a further possibility of appeal even though the Court of Appeal is a court very high in the hierarchy of the Greek justice system.

Different systems of mediators have been adopted by the legislations of several member states. Perhaps the most similar to the Greek one is that of France. According to the French implementation the parties can refer to a three person mediator body and have the right to appeal to the Court d' Appel of Paris. Similarly, in Italy the parties can complain to a Permanent Copyright Consulting Committee and are given the right of appeal to the court. While in Portugal the parties can complaint to the Comissao de Mediacao e Arbitragem which is the equivalent to a small claims court whose decisions have judicial value. This body was created by law 83/2001 and accepts only cases about access to copyright works for lawful uses. No provision for appeal is mentioned. Judicial order for such cases is provided by the Austrian and German implementation. 
Interface between Technological Protection Measures and the Exemptions to Copyright

It would be also useful to see the relevant measures taken by Denmark which was also one of the very first member states to implement. In Denmark the parties can refer to the Board of Intellectual Property Rights and there is also the possibility of appeal to the court. The different point to that of the Greek implementation is that users may circumvent if the rightholder ignores their circumvention longer than four weeks. This is indeed a provision highly beneficial for the public and is an example of how the severity of the directive can be moderated through national implementation.

Furthermore, no reference is provided in Greece as regards the 'private copying exception' which has been a very controversial issue in the UK. Circumvention research exemption is recognised through the implementation procedures only in Denmark and Finland. It is also recognised in Germany via the Constitution. Therefore, it can be concluded that although the Copyright Directive is a very important step in the direction of harmonisation of European copyright law, the approach in Europe towards private copying, technological protection measures and copyright levies is chaotic (Hart, 2002).

\section{United Kingdom}

The process of the implementation in the UK has been rather unpredictable. The public awareness about the issues raised by the Directive led the UK Patent Office, which was overseeing the consultation to implementation, to withdraw its proposal for fast-track implementation.

The implementation was finally made by the Statutory Instrument 2003 No.2498 by the end of 2003. As it is stated at the end of the instrument 'The Copyright, Designs and Patents Act 1988 ("the Act") already provides protection similar to many of the obligations contained in the Directive. These Regulations amend the Act insofar as its provisions do not conform or comply with the Directive and regarding matters that are related to or consequential upon these obligations.'

Article 6(4) of the Copyright Directive was implemented in the UK legislation through section 296ZE with the title 'remedy where the effective technological measures prevent permitted acts'. In fact this paragraph presents one of the most controversial aspects of the government's proposals. According to the procedure described a beneficiary must wait for an undefined period of time for voluntary agreements to be concluded by the rightholders. If those do not cooperate then he or she can refer to the Secretary of State who will issue a direction for the rightholder in order to ensure that the owner of the exclusive work will make available to the complainant the means of carrying out the permitted act. If these directions are ignored then the beneficiary has the right to take action against the copyright holder for a breach of statutory duty.

This kind of state measures for the implementation of article 6(4) is unique in the EU since no other national law refers to a complaint to the Minister or another governmental body. Perhaps the other European system that comes close to the UK is that of Spain. According to the Spanish implementation the Commission on Intellectual Property may recommend a penalty of 6000 euro per day to the Ministry of Education, Culture and Sport.

In my view this system is not the most appropriate to ensure the rights of the users since it is state oriented. There is not an independent body that makes the final decision such as a self-regulatory commission or a court. In contrast, it is only the government that takes the most crucial decisions for the public interest. After taking into account the pressures that the industry puts on the governments in a national, European and international level I do not hold that this is the most trustworthy and independent system.

Further, there are no provisions for the protection of free speech or privacy rights against technological protection measures. Nevertheless, the UK Human Rights Act 1998 will allow courts to read the provisions of the copyright legislation in a way that is consistent with the rights protected 
by the Act or even notify the Parliament that changes are needed in the legislation in order to include the rights of privacy and free speech. The Data protection Act 1998, which implements the EU Data protection Directive, will also apply (Brown \& Bohm, n.d., p. 4).

Another very important point as concerns the implementation of article 6 (4) is the absence of specific protection for research activities, although the government had indicated in June 2003 that it would look at this issue carefully and would provide such a mechanism (http://www.patent.gov.uk/copy/notices/implementation.htm dated 18 June 2003) As it is mentioned above it is only Denmark, Austria and Germany that have recognised this right.

Indeed, one of the implications in the research activities is caused by the fact that after the implementation of the new directive into the UK national legislation copying for commercial purposes is no longer accepted. The British Library has made some Guidelines which suggest that 'commercial purposes' is a fairly wide term which may cause many unpredictable obstacles to the users. For instance a writer which is researching in libraries in order to publish a book will be copying for commercial purposes. Similarly, copying carried out by a charity for the purpose of raising funds can be also considered as copying for commercial purposes. Moreover, a commercial law firm copying for a pro bono matter will generally be considered as non-commercial (although if the pro bono work was carried out in the hope of generating more work, the copying should be considered commercial).

In addition, the last part of this section does not include in this procedure 'copyright works made available by an on-demand service' along with performance, database and publication rights as the article 6(4) (4) requires. Perhaps this exclusion was made under the general approach of the UK government which wished to amend the existing exceptions of the Copyright Act where required to comply with the Directive but in general not to introduce new exceptions permitted by the Directive where these were not already part of the UK law (Brown \& Bohm, n.d., p. 1). Indeed, as mentioned in chapter 2.2.2 of this paper the definition of on-demand services was rather broad and this fact apparently created one more difficulty in the implementation procedure.

\section{Norway}

Norway at the moment, spring 2004, is still in the process of implementation. The Norwegian green paper suggests a mechanism to ensure that rightholders respect certain copyright exceptions favoring certain user groups. This paper includes the proposal of the Ministry of Culture and Church Affairs for the creation of a mechanism that gives the power to instruct rightholders to enable such fair use that follows from sect. 13/13a (educational), 15 (institutional), 16 (libraries), 17/17a (functionally disabled), 21 (educational), 26-28 (public negotiations, inquiries etc), and 31 (ephemeral recordings) in the Norwegian Copyright Act.

According to this proposed mechanisms rightholders utilizing technological measures to protect their works will be obliged to enable such use that the mentioned provisions dictate.

However, if any of the mentioned user groups are not, within reasonable time, granted such access, a separate committee shall have the power to instruct the concerned rightholders to hand over the tools or information required to enable such use. The committee shall be appointed by the Ministry of Culture and Church Affairs and shall consist of representatives of both the userand rightholder-groups, in addition to a neutral chairman appointed by the Ministry. Therefore, in the case of Norway as in the UK we can also observe the interest of the government to be involved in this procedure. I have stated my objections to such interference in the previous section (3.2). With such interference there is always the danger that the pressures of the industry to the government might be reflected in the decisions of the appointed committee. Of course it is important that there is mixed representation in the committee and this may serve the balancing of the contrasting interests. 
Interface between Technological Protection Measures and the Exemptions to Copyright

The exact procedural rules will be laid down in subordinate legislation which is not yet proposed. But the Ministry has already now excluded the option of an administrative appeal. The decisions of the committee shall, however, be subject to review by the courts. This constitutes an acceptable remedy as soon as this court review can be further examined by a higher court through an appeal procedure. We have also seen in the Greek example the lack of further appeal procedure. There if one of the parties does not accept the recommendations made by the mediators within one month the dispute will be settled by the Court of Appeal without any further possibility to appeal.

Another implication of this proposal drawn by the association of the Norwegian record companies, FONO, is the fact the wording of the proposal implies that the interested parties could refer directly to the Committee instead of trying to find a solution through negotiation at the first place. Similar are the remarks of KOPINOR, The Reproduction Rights Organisation of Norway, which states that it should be made clear that the voluntary measures are the first and more important step in this procedure.

Further, the Ministry has presupposed that the committee shall have the power to state a timelimit, within which the tools or information can be handed over by the rightholders. Further, the committee shall have the power to decide that if access has not been enabled within the established time-limit, the user shall have the right with impunity to circumvent the technological measures, to the extent needed to enable the entitled use.

In this point Norway is following the example of Denmark where users may circumvent if the rightholder ignores their circumvention longer than four weeks. As I have also stated above, this is a provision highly beneficial for the public and is an example of how the severity of the directive can be moderated through national implementation. However, the NRK, the Norwegian Broadcasting Corporation, doubted the effectivevess of such provision. Their objection is that it might take too long time for the user to obtain her right.

The Norwegian mechanism shall not apply to computer programs or contractual on-demand services where each user him/herself determines the time and place of access. The proposed provision is section $53 \mathrm{~b}$. Also, the private use exception in section 12 of the Norwegian Copyright Act is not governed by the proposed provision.

\section{Critical Review of the Digital Millennium Copyright Act and the EC Directive}

After having examined the relevant legulatory framework from both sides of the Atlantic this chapter shall be engaged with a comparative analysis of the two different legislatory measures and in particular of article 6 (4) of the Copyright Directive and section 1201 of the DMCA which deals with the copyright exemptions.

In addition, I shall try to critically explore these provisions by examining the opposite interests of the public and copyright holders, the impact on the rights of the users and finally the effectiveness of the provisions

\section{Comparison of the US and European Perspective}

As it is stated in the second chapter both the Copyright Directive and the Digital Millennium Copyright Act had as their main objective to harmonise their legal systems with the 1996 WIPO Treaties. However, the way in which they implemented the article 11 of the WIPO Copyright Treaty was not identical.

In particular, the Copyright Directive which was created three years after the DMCA, tried to follow the basic guidelines of the DMCA. However, many points as concerns to the exemptions 
from copyright are not clear enough. A comparative analysis between these two jurisdictions will be made in this chapter.

\section{The interface between the technological protection measures and the exemptions to copyright, section 1201 DMCA, article 6 (4)}

As far as the DMCA and the Directive try to provide exemptions for their strong anticircumvention provisions, the question of flexibility becomes crucial. Copyright statutes should remain relevant despite technological change and ensure that future innovation will not diminish the effectiveness of the overall policy. In the field of exemptions both the DMCA and the Directive try to provide for a certain amount of flexibility (Fallenbock, 2002/2003, p. 42-43). However, the way in which they try to achieve this goal differs.

Nevertheless, the Infosoc Directive is not that clear as comes to the exemptions since nothing in the wording of article 6 could be construed in the author's view as considering the protection not to cover the exercise of the exemptions. A heavy burden is being placed upon the users to exercise their legitimate exemptions since they can be prosecuted for circumvention even if they are considered non liable for copyright infringement (Dusollier, 1999)

Therefore, unlike the DMCA, article 6 (4) does not give protection to certain groups such as security researchers, against liability for circumvention offences. In the first instance it merely requests that rightholders take voluntary measures to allow the exercise of certain exceptions. Recital 51 emphasises that these may include the "conclusion and implementation of agreements between rightholders and other parties concerned' (Brown \& Bohm, n.d., p. 9).

As concerns the notion of 'effective measures' article 6(3) provides the following definition "Technological measures shall be deemed "effective" where the use of a protected work or other subject-matter is controlled by the rightholders through application of an access control or protection process, such as encryption, scrambling or other transformation of the work or other subjectmatter or a copy control mechanism, which achieves the protection objective'. On the other hand, the DMCA in section 1201 (b) (2) (B) provides that: 'a technological protection measure effectively protects a right of a copyright owner under this title if the measure in the ordinary scope of its operation prevents, restricts or otherwise limits the exercise of a right of a copyright owner'.

This exact definition given by the Act has as a result the better protection of the 'fair use' doctrine. While, in contrast, the definition given by the Infosoc Directive actually deems as effective all the encryption methods used for the protection of the rights of copyrightholders. The DMCA gives more direct interpretation of the use of the protection measures, they should 'prevent, restrict, limit'. The directive does not define 'the protection objective'. Its wording is vague and leaves much room for the right holders to interpret it.

The House Committee on Commerce in the US considered effective only those measures that require the use of a 'key' provided by the copyright holder. Thus, for example measures that meter use cannot be covered. Since only measures that protect copyright are considered effective, a technological measure is not protected when it prevents acts that constitute fair use or otherwise permitted under copyright law (Koelman \& Helberger, 2000)

However, this is still a problematic area for article 6(4) which does not explicitly protect acts of circumvention which are made for the exercise of legal rights which derive from the 'fair use' doctrine.

\section{Common principles: Policy reasons and objectives}

The industries which supply the intellectual material for science and innovation as well as for education and instruction in general, have helped bring about dramatic increases in productivity 
Interface between Technological Protection Measures and the Exemptions to Copyright

through aiding the creation of information based products like desk-top publishing software, electronic mail or sophisticated scientific computer databases.

Moreover, the copyright industries have developed into a huge source of wealth and employment creation in the knowledge based global economy. In the US their overall combined value has increased at such a rapid rate in the last twenty or thirty years, that together they currently contribute more than $\$ 460$ billion to US gross domestic product and sold almost $\$ 80$ billion in exports in 1999 (European Commission Report, 2000, p. 95).

It is easy to understand why the US and EU aim through the DMCA and the Copyright Directive to regulate the knowledge based industries and create all the necessary conditions for its development. Nevertheless, this policy has placed the public interest at a significant disadvantage.

In 2001 and 2002, copyright interests had moved their attention to a new front: ensuring that personal computer and other digital tools can't be used to make copies of commercial content (Godwin, 2003). Therefore, as in the US, the initial approach of the European politicians has been hard line with the copyright Directive conceived as European equivalents to the DMCA (Poynder, 2001).

During the drafting of the Copyright Directive some thought that Europe would act as a counter balance and play a stabilising role in the debate over copyright. It was hoped by liberals that one of the major differences between the EU Copyright Directive and the DMCA would be a more consumer focused approach. These hopes were based on the fact that EU Copyright Directive specifies that copyright owners can only use technology to prevent copies provided they have systems in place to allow people who are exempted from the copyright controls to make copies. Such systems can be considered the voluntary measures taken by the right holders, article 6(4).

However, after having examined all the disadvantages that are caused by the imprecise wording of article 6 (4) I doubt that the Directive has actually managed to fulfil the expectations for a more consumer focused approach. Indeed, the exemptions of copyright are seriously threatened by the vagueness of article 6(4).

In a further level of analysis, it is crucial to see what the impact of the DMCA and the Copyright Directive has on the developing countries. Copyright related issues have become increasingly relevant and important for developing countries as they enter the information age and struggle to participate in the knowledge based economy. Hence, stronger copyright protection may prohibit access of these countries to the rapid advancements in information and communication technology, transforming the production, dissemination and storage of information (European Commission Report, 2000, p. 96).

In concluding, I consider that both s.1201 DMCA and article 6(4) of the Copyright Directive have as main objective the protection of the rights of the copyright holders and the industry in order to reassure their best function for their economies. This is why, in comparison to the exemptions of traditional copyright, the exemptions of copyright provided by these two legislatory measures are definitely restricted.

\section{The opposite interests of the public and copyright holders}

As it has been pointedly said 'an increased 'propertisation' of knowledge involves the risk that the balance between the individual rights and the general interest will be upset' (Poynder, 2001). This sentence sums up my argument about the imbalance concerning the rights of the users and the rightholders. Indeed, as Lawrence Lessig sees it 'the future of ideas' is at stake (Bowrey \& Rimmer, 2002). 
In order to examine in practice what are the conflicting interests of the public and the copyright holders it is useful to refer to the different responses of the civil society groups, which mostly support the rights of the users.

In fact I have chosen to examine these developments in the member states whose implementation procedure was discussed in the previous chapter: UK, Greece and Norway. Certainly, the responses of a range of different groups of the civil society are very interesting and well-argued and in this conflict I mostly support their point of view.

\section{The impact on the rights of the users}

The negative impact on the rights of the users is one of the most problematic areas in the Directive and can be considered as one of the main obstacles that the governments have faced for its implementation. This impact shall be assessed in this paragraph by presenting the responses and suggestions of the civil society to the governments as regards to the implementation of the Infosoc Directive in the national law.

Firstly, I agree with the harsh criticism by Bernt Hugenholtz (2000) on the Directive. I also consider that these disadvantages that are pointedly presented by him resulted in the lower position of the rights of the public in comparison to the rights of the rightholders. As he has stated: 'The intense pressure from the copyright industries and, particularly, from the United States (where the main right holders of the world reside), to finish the job as quickly as possible, has not allowed the Member States and their parliaments, or even the European Parliament, to adequately reflect upon the many questions put before them'.

Into this environment stopped a number of non-governmental organisations which stated their opposition to the national governments. In the UK the government received over 300 responses on the implementation of the Directive (Brown \& Bohm, n.d.). The Foundation for Information Policy Research which studies the interaction between information technology and society pointed out some of the difficult areas of the Directive by giving its suggestions upon which I agree.

In particular, it suggested that the implementation should fully respect the reverse engineering provisions in the EU Software Directive for both software and file formats. A clear and broad exemption for security research should be included and any prosecutions made under anticircumvention powers should require the approval of Attorney general, to ensure that wider policy interests are considered.

From the same point of view the Campaign for Digital Rights supported that cryptography research must be protected, as recital 48 of the Directive states. Research into the effectiveness of the security algorithms and systems should not be prevented merely because they might be used in a technological protection mechanism. Indeed, I agree with this statement since the evolution of science should not be prevented through the anti-circumvention provisions.

Furthermore, practical problems can be created in the routine of certain jobs. For example, as the report states, music studios, broadcasters and other media organisations routinely need to copy media as part of their business functions. In addition, the Norwegian Library Association in its response to the government's proposal for the implementation of the Infosoc Directive stated that the new regime will create new conditions in the scientific research within libraries because it will mean more complex and time consuming processes.

While, software developers could be put in a precarious position since they need to circumvent technological protection measures in order to reverse engineer a piece of software in its file formats, which is explicitly allowed by under current UK and European law for interoperability purposes. It is also true that those who wish to create innovative new platforms and devices will be 
Interface between Technological Protection Measures and the Exemptions to Copyright

prohibited by the new legal measures which create legal obstacles to their research or make it extremely expensive. In addition, I agree with the proposal that works should be provided in unprotected form to archivists who will be able to make them available to the public once the copy has expired.

I also favour the arguments of the Libraries and Archives Copyright Alliance which feels that since the Directive took the wrong approach in protecting technical measures even against the exercise of fair dealing rights, a good implementation of article 6 (4) is critical. They pointedly argue that 'creators in every field of endeavour are also users of copyrighted materials. A lack of access to them, where the original author suffers no significant damage, will in turn impede or even obstruct research and the making of further works'.

On the other hand the arguments of the British Phonographic Industry present the positive effects of the new provisions to the record industry and do not mention their negative implications to the rights of the users. In particular, they state that strong protection of technical measures under the articles 6 and 7 is vital. These are important 'to the growth of new e-business' and 'enable record companies to create a wide range of listening or copying options for the consumer'. They even propose the broadness of existing controls in the provision of devices that circumvent controls or remove rights management information. I believe that this point of view is one-sided since it only supports the interests of the industry and ignores the rights of the users which are restricted through the strong protection of technical measures.

As far as concerns the reactions of the civil society in Greece I could mention the statement issued after promulgation of the law 3057/2003 for the implementation of the Directive by the Hellenic Linux Users Groups which complained about the excessively restrictive effects of technological protection measures, especially regarding the use of audio CDs and region-locked DVDs.

In addition, I am of the same opinion with the critical voices emanated from Digital Rights Greece, an online site dedicated to promoting the freedom of speech online. In particular, they complained that the restrictions posed on article 6 end up imposing overshoot the needs of copyright protection. They strictly point out that the exceptions to the rules of article 6 of the Directive are practically insignificant.

In contrast, different views in favour of the industry are presented by organisations such as the Business software alliance or the Union of Greek producers of Phonograms (the Greek branch of the International Federation of Phonographic industry). In fact, anxious to see piracy curbed, predictably expressed themselves in favour of strict measures of protection of intellectual property rights and consider the provisions of the Directive as a step of the right direction (Maroulis, n.d., p.5). As expected, no mention was made about the exemptions and the impact of the provisions to the rights of the users.

The same debate takes place in the other side of the Atlantic where the Recording Industry Association of America instrumentally uses the legislature and the US courts to advance their sectional interests. Jill Lesser, AOL Time Warner's senior vice president for domestic public policy stated: 'We like the DMCA. There isn't from our perspective a need for additional remedies of copyright violations' (Godwin, 2003).

On the other hand, the academics acknowledge the philosophy expressed in the Intellectual Property provisions expressed in the American Constitution:

Article 1, Section 8, Clause 8. The Congress shall have power to promote the progress of science and the useful arts, by securing for limited time to authors and inventors the exclusive right to their respective writings and discoveries. 
This clause legitimates the interpretation of copyright as a limited and socially responsible property right that is one of the balances owner's and user's interests (Bowrey \& Rimmer, 2002). In concluding, after having examined this tension among the different groups it is easier to comprehend the notion of 'digital dilemma' which arises from the ability to produce large quantities of copies in breach of copyright. Indeed, under these developments the balance of power between the interests of the copyright holders and the interests of information users has shifted radically in favour of the latter (Bygrave, 2002b, vol. 24).

\section{The effectiveness of the provisions}

The following criticism about the effectiveness of the anti-copying provisions is not only about article 6(4) but also about the general legal, economic and political approach of the public interest in the Directive. In this paragraph I will explain the reasons that lead me to suggest the reconstruction of article 6 (4) and the adding of a new article in the Infosoc Directive.

In his book Code and other laws of Cyberspace, Professor Lessig points out that there are four basic ways for society to regulate the behaviour of its members: through the law, through the social norms (essentially pricing), through the market forces and through architecture (technological constraints). He adds that if the laws have become too draconian, then people are inclined to simply ignore them, for example as many currently do with speed limits (Poynder, 2001).

Same is the result in the laws referring to protection of copyright in the digital environment. The fact that KAZAA and other websites for free software circulation is being used by millions of users every day shows not only the ineffectiveness of the provisions but also the attitude of the public towards them.

The reasons that lead me to conclude to ineffectiveness and to give the suggestions set forward in the next paragraph are the overprotection of the right holders, the public interest, the lawful exercise of circumvention, the technological evolution, the need for privacy and data protection and the need for cultural diversity.

I have discussed in the previous chapters about how effective these measures may be for the interests of the copyright holders. In brief, I consider that the provisions are very effective when it comes to circumvention. Of course it is impossible to prevent every kind of circumvention. There will always be a certain group of users who will have the skills and motivation to circumvent the technological protection measures, but the new anticircumvention provisions and particularly those which prohibit the trafficking of circumvention devices exclude the vast majority of the users from anticircumvention since they lack the technical expertise (Fallenbock, 2002/2003).

Also, much discussion has been done about the end of the public domain, in a totally controlled system where no need for protection erga onmes will remain (Hugenholtz, 1999). I am concerned about the questions posed by the academics 'are we heading for a world in which each and every use of information is dictated by fully automated systems? A world in which what is allowed and what is not is no longer decided by the law but by computer code? Will 'code' replace the law? The true technocrat would marvel the idea.' (Hugenholtz, 1999). 'Should our beautiful system of statutory limitations be left to the museum of Copyright?' or 'What if the information consumer is notified in advance that the computer game he is going buys may be played only X times, the book may be copied only Y times, the music may be enjoyed only $Z$ times?'

These questions show the agony of the academic world that we are heading towards a 'pay-perview' society where technical protection measures will actually limit the access and use of the information products by the public. The obstacles put to the fair use doctrine by the new provisions have consequently led to harsh criticism. It is interesting to mention the words of B.F.Fitzgerald as an example of such criticism: 'Perhaps things might work better without fair use and that holding on to such principle in the digital crypto world is conservative and dated. 
Interface between Technological Protection Measures and the Exemptions to Copyright

However, I'm yet to be convinced that I am a dinosaur or that the demise of fair use is a good thing' (Fitzgerald, 2001).

The most interesting issue could be considered as the use of anticircumvention tools by the public when exercising their lawful prerogatives. I shall mention here the example of the writer Stephen King who, in mid-2000 decided to experiment with online distribution of his fiction. He is a Macintosh user and his novel was distributed only on Intel based PCs running the Windows operating system. So he himself and his audience were not allowed according to the DMCA to reverseengineer a way of reading his novel in Macintosh computer or sidestep the e-book's encryption and extract the story for easy readability on the reader's PowerBook (Godwin, 2003).

As a result of these consequences of the law, the DMCA was criticised by Litman as 'long, internally inconsistent, difficult even for copyright experts to explain [...] the law seeks for the first time to impose liability on ordinary citizens for violation of provisions that they have no reason to suspect are part of the law, and to make non-commercial and non infringing behaviour illegal on the theory that it will help prevent (copyright) piracy' (Godwin, 2003).

Furthermore, the effectiveness of the new provisions can easily be challenged by the evolution of technology which can render this regime out of date. For this purpose, it is provided that periodically the Commission shall submit to the European Parliament, the Council and the European Committee a report on the application of the Infosoc Directive in which it will examine the application of article 6 in the light of the development of the digital market. In particular it is to examine whether article 6 confers a sufficient level of protection and whether acts which are permitted by law are being adversely affected by the use of effective technological measures (Hart, 2002).

Another problematic area as comes to the effectiveness of the provisions is the protection of privacy and data protection. Indeed, the name of the viewer, the material being viewed, the device where the material is being viewed or other sensitive data in a personal, commercial and political manner can be available to the rightholder.

The first use of such data is related to marketing. The trails come together to make a pattern of consumption and movement. This will be valuable to enterprises marketing a certain product or operating within a certain geographic area. The value of information for high quality, selective mail is high. Then a second situation is that of individual and collective surveillance. By individual surveillance a situation is perceived in which the attention of the authorities is directed towards a certain person. In collective surveillance data is used for statistical purposes such as the creation of a 'profile' in order to identify individuals for example the 'profile' of a terrorist.

Technological measures have frequently been accused as being privacy-invasive. Thus many national laws encourage the development and application of the least privacy-invasive measures following mostly the provisions of the Data protection Directive. Such legal actions have been taken for example in Germany (Bygrave, 2002).

Speaking of privacy and data, the new provisions allow copyright holders to protect their works with any technological measure that is effective and user-friendly. Nevertheless, this creates a special problem to the internet users who expect seamless surfing from one website to another and even simple identification mechanisms deter a high percentage of users from further proceeding in their search of information (Fallenbock, 2002/2003).

Many EU states such as France are particularly concerned about the homogenisation of culture. They have resisted attacks on their national quotas for films, music and movies through free trade. I agree with the view that they should also resist attempts by large global corporations to lock up content through increasingly strong intellectual property rights and reducing the rights of European artists to build on previous works (Brown \& Bohm, n.d., p.5). This would result in putting up barriers in the evolution of artistic creativity. I am also for the opinion that long term pol- 
icy objectives such as competition, free expression, privacy and cultural diversity must all be supported rather than hindered by Copyright Law (Brown \& Bohm, n.d., p.4).

\section{Suggestions for the reconstruction of article 6 and the creation of a new article in the Infosoc Directive.}

After having examined the above mentioned problematic areas, I advance the following proposals. I agree with the critical point of view of EBLIDA. EBLIDA functions as the umbrella association for library, information and documentation associations and all kinds of libraries throughout Europe. At the moment EBLIDA represents over 95.000 libraries. This organisation stressed the need for adequate protection of Copyright in the new digital area. In particular, EBLIDA proposed a revision of article 6 underlying the importance of balance in copyright (EBLIDA, 1998).

Consequently, I agree with its proposal for a revision of article 6 as following: Member States shall provide adequate legal protection and effective legal remedies against the circumvention of effective technological measures that are used by rightsholders in connection with the exercise of their rights under the WIPO Copyright Treaty or the Berne Convention and that restrict acts, in respect of their works, which are not authorised by the rightholders concerned or permitted by law.

The justification given for this proposal states that this revision is almost identical with Article 11 of WIPO Copyright Treaty 1996. The circumvention of technical measures should be allowed for activities authorised by the copyright owners or permitted by law, as well as the production and marketing of devices designed to circumvent technical measures to facilitate the making of noninfringing copies.

Moreover, I suggest that not only the revision of article 6(4) is required but also the adding of a new article which gives in a definite way a 'fair use' exemption. I would not suggest an article similar to the exemptions' provision of the DMCA but a more concrete and clear provision which reassures without doubt the rights of the users. As Lessig stated before when the law is too draconian people do not obey. Therefore, the law should be in accordance with the new needs and do not actually push people to act against it while their actions are actually fair.

A reasonable example of such provisions that could obtain the form of a general article about fair use is sections 29, 30 and 31 of the Copyright, Designs and Patents Act 1988 in the UK before the amendments for the implementation of the Directive. In particular, I suggest the creation of a general article about fair use consisted by three paragraphs:

a. Research and private study. Fair dealing with a literary work, other than a database, or a dramatic, musical or artistic work for the purposes of research or private study does not infringing any copyright in the work or, in the case of public edition the typographical arrangement.

b. Criticism, review and news reporting. Fair dealing with a work for the purpose of criticism or review, or that of another work or for performance of a work, does not infringe any copyright in the work provided that it is accompanied by a sufficient acknowledgement.

c. Incidental inclusion of copyright material. Copyright in a work is not infringed by its incidental inclusion in an artistic work, sound recording film, broadcast or cable programme.

For the creation of such a provision it would be necessary that article 5 of the Infosoc Directive does not focus on exemptions only when there is not a commercial interest. I have already pointed the difficulties that this precondition may cause. 
Interface between Technological Protection Measures and the Exemptions to Copyright

Finally, there are very good grounds for agreeing with this proposal because it would be better for both sides, copyright holders and public, if the copyright holders were trying to explore the cyberspace and find some new ways of communication with the public. It would be much more preferable to exploit the new possibilities for the benefit of their industry rather than fighting constantly against the digital challenges.

\section{Conclusion: The Balance of Copyright Protection Measures in the Digital Environment}

After having examined the provisions regarding technological protection measures from an international, US, European and member states' perspective I have come to the conclusion that the new regulatory measures, article 6(4) of the Infosoc Directive and section 1201 of the DMCA, are mostly for the benefit of the copyright holders in disadvantage of the users' rights and the public interest. There are very good grounds for agreeing that the balance of the rights of these two groups is threatened by the overprotection of technology and the exercise of the legal rights of the users impose a heavy burden on them.

In addition, this complex situation of the exercise of the exemptions is being more difficult due to the vague statutory language which adopts many broad terms such as 'appropriate measures' or 'on-demand services' without giving sufficient definitions. Then, the national legislator is in the challenging position to 'translate' the directive in a way that would serve best the certain situations which appear in her own jurisdiction.

By comparing and contrasting the methods of implementation of article 6(4) in the national jurisdictions I've reached the conclusion that independent or judicial bodies are more appropriate than governmental agencies to ensure that rightholders make available to the beneficiary of an exception or limitation provided for in national law. This system ensures better the rights of the users because it is not affected by governmental decisions which might favour the rights of the pressing industry.

Another important point when it comes to the creation of the law is that the legislators in national and international level should foresee the evolutions of technology and create the legislatory framework before the difficulties arise instead of just following the developments. It is true that in our age technology advances so rapidly that the law struggles to keep up. This is also one of the issues in the DMCA and the Copyright Directive. As the US Democrat Representative, Rick Boucher, has stated what matters is whether new technologies are consistent with the theory of copyright laws and not with the details of the copyright law (Poynder, 2001).

In addition, the balance that intellectual property law traditionally strikes is between the protections granted the author and the public use or access granted everybody else. The aim is to give the author sufficient incentive to produce (Lessig, 1999). However, this aim should not pose obstacles to the evolution of science through the building of new creations based on older copyright protected works or the exercise of legal rights of the users such as the 'fair use' accepted by the traditional copyright law.

All legislative bodies that have taken on protection of technological measures stress that the balance that is struck in copyright law between the interests of the right-holders and the users must be maintained. The Preamble of the WIPO Copyright Treaty states that the Treaty is drafted while: 'Recognising the need to maintain a balance between the rights of the authors and the larger public interest, particularly education, research and access to information, as reflected in the Berne Convention'. Similarly, in recital 21 of the EU Directive it is considered that 'a fair balance' must be safeguarded. Also, the US legislature underscores that a balance between interests 
of both parties must be struck when the protection of technological measures is concerned (Koelman \& Helberger, 2000).

In concluding, harmonised protection which guaranties at the same time the interests of the users and ensures access to information and knowledge for all would be desirable (de Kroon, 2000).

It remains to be seen how the voluntary measures and the appropriate state measures for the protection of the public rights will function. Obviously, the appropriateness of the changes I suggest would only be able to be assessed in light of the eventual case-law from ECJ and the report of the Commission on implementation of the Directive.

In concluding, it is worth mentioning the wider international harmonisation issues. As it has been said copyright is at once the most 'domestic' and 'cosmopolitan' form of property (Fitzpatrick, 2003). The harmonisation of copyright law across the globe through international treaties such as the WIPO Treaties in 1996 presupposes greater communality of interests between states.

However, the gap between the developed and the developing countries is still enormous in the use of information communication technology. As the reports of UNESCO showed in 1996 the US, Europe and Japan accounted 79 per cent of the world's personal computers while the African continent had 1.3 per cent (Fitzpatrick, 2003).

Indeed, the impact of these figures on harmonisation is enormous. Developing countries do not favour the paying of expensive foreign products of the information society. It is rational for these states to consider that their domestic national interest in education, science, public administration and all the sectors where copyright products are used is more important than the benefit of the authors. As a consequence since the interests of the industry in the western world and the needs of the developing countries diverge harmonisation in an international level is a goal difficult to be achieved.

Finally, as copyright works are digitally accessible on a global basis, international harmonization would not only be a positive development, but by permitting the use of technological protection measures and taking into account the fair use exemptions, would take a realistic and crucial approach to the expanding economies and civil societies in an ever shrinking world.

\section{References}

\section{List of Judgements/Decisions}

University London Press Ltd v University Tutorial Press Ltd. (1916). 2 Ch 601 at 610 per Petersen J.

International News Service v. Associated Press (1918)

\section{Treaties/Statutes}

The Digital Millennium Copyright Act of 1998

The Directive 2001/29/EC on the harmonisation of certain aspects of Copyright and Related Rights in the information society

WIPO Copyright Treaty 1996

European Commission, (7 December 2000) Sixth report for the implementation of the telecommunications regulatory package

\section{Secondary Literature}

Anderman, S. D. (1998). EC competition law and intellectual property rights. Oxford. 
Interface between Technological Protection Measures and the Exemptions to Copyright

Anderson. R. (n.d.). The Draft IPR Enforcement Directive - A Threat to Competition and to Liberty. Retrieved from http://www.fipr.org/copyright/draft-ipr-enforce.html

Becker, Buhse, Gunnewig, \& Rumb. (2003). Digital rights Management: Technological, economic, legal, political aspects. Berlin: Springer.

Bently, L. \& Sherman, B. (2001). Intellectual property law. Oxford University Press.

Bing, J. (1992). Data protection in a time of changes. Kluwer Law and Taxation.

Bing, J. (2002). Intellectual property exclusive access rights and some policy implications, Scandinavian Studies in Law, vol. 42

Braun, N. (2003). The interface between the protection of technological measures and the exercise of exemptions to copyright and related rights: comparing the situation in the United States and in the European Community. European Intellectual Property Review, 25(11), 499, 501

Brown, I. \& Bohm, N. (n.d.). UK implementation of the directive. Retrieved from http://www.fipr.org/copyright/guide/uk.htm

Bowrey, K. \& Rimmer, M. (2002). Rip, mix, burn: The politics of peer to peer and copyright law. First Monday, 7(8), 2,4,7,17,23.

Bygrave, L. A. (2002a). Data protection law: Approaching its rational, logic and limits. Kluer Law International, 57.

Bygrave, L. A. (2002b). The technologisation of copyright: Implications for privacy and related interests. European Intellectual Property Review, 24, 52.

Bygrave, L. A. (2003). Digital rights management and privacy- Legal aspects in the European Union. In Becker, Buhse, Gunnewig, \& Rumb (Eds.), Digital rights management: Technological, economic, legal, political aspects (p. 443). Berlin: Springer.

Clark, C. (1996). The answer to the machine is the machine. In B. Hugenholtz, The future of copyright in the digital environment, (pp. 139-146).

Commission on Intellectual Property Rights (U.K.). (2002, September). Integrating Intellectual Property Rights and Development Policy, Chapter 5.

Cornish, W.R. \& Llewelyn, D. (2003). Intellectual Property: Patents, copyright, trade marks and allied rights, ( $5^{\text {th }}$ ed.). Sweet and Maxwell.

de Kroon, (2002) Protection of copyright management information. In P.B. Hugenholtz (Ed.), Copyright and electronic commerce (pp. 240, 262). Kluer Law International.

The "Digital Divide" in Greece. (n.d) Organisation for Economic Co-operation and Development [Room Document].

Dusollier, S. (1999). Electrifying the fence: The legal protection of technological measures for protecting copyright. European and Intellectual Property Law Review, 285, 288, 294

EBLIDA. (1998 March). Save future access to information now. EBLIDA position paper on the proposed directive on the harmonisation of certain aspects of copyright and related rights in the Information Society

Electronic Privacy Information Center. (2000). Cryptography and Liberty 2000, An international survey of encryption policy. Washington, DC.

European Commission Report. (2000, December 7). Integrating Intellectual Property Rights and Development Policy. Copyright, Software and the Internet.

Fallenbock, M. (2002/2003 Winter). On the technical protection of copyright: The digital millennium copyright act, the european community copyright directive and their anticircumvention provisions. International Journal of Communications Law and Policy, 7, 5-8, 21,35 
Fitzgerald, B.F. (2001). Digital property: The ultimate boundary? Roger Williams University Law Review, $7(1), 38$.

Fitzpatrick, S. A. (2003). Prospects of further copyright harmonisation? European Intellectual Property Review, 25(5), 33, 215.

Godwin, M. (2003). Cyber rights: Defending free speech in the digital age (pp. 225, 232,238). Massachusetts Institute of Technology.

Greenleaf, G. (1998). An endnote on regulating cyberspace: Architecture v. law. University of New South Wales Law Journal.

Guadamuz. (2002).Trouble with prime numbers: DeCSS, DVD and the protection of proprietary encryption tools. Journal of Information, Law and Technology, 3.

Hart, M. (2002). The copyright in the information society directive: An overview. European Intellectual Property Review, 24, 4, 58, 63-64.

Hugenholtz, P. B. (1999). Code as code, or the end of intellectual property as we know it. Maastricht Journal of European and Comparative Law, 6, 174, 308, 311, 313, 317.

Hugenholtz, P. B. (2000). Why the copyright directive is unimportant, and possibly invalid. EIPR 11, 501502.

Iglezakis, I. (2003). Greece: Implementing the copyright directive. Computer und Recht International, 1, 28.

IT \& Public Policy. (1998 Summer). UK Parliamentary IT Committee, 16(3).

Kallinikou, D. (2000). Intellectual property and relative rights. Athens: Sakkoulas.

Kallinikou, D. (2001). Intellectual property and Internet (p. 81). Athens: Sakkoulas.

Koelman, K. J. \& Helberger, N. (2000). Protection of technological measures. In P.B. Hugenholtz (Ed.), Copyright and electronic commerce (pp. 175, 177, 192, 195). Kluer Law International.

Lessig, L. (1999). Code and other laws of cyberspace (pp. 125, 134). Basic Books.

Lim, Y. L. (2002). Cyberspace law (pp. 189, 382-383). Oxford University Press.

Maroulis, V. (n.d.). The implementation of the directive in Greece. Retrieved from: http://fipr.org/copyright/guide/greece.htm

O'Sullivan, M. (2002). Making copyright ambidextrous: An expose of copyleft. Journal of Information Law and Technology, 3(11), 24.

Poynder, R. (2001). Caught in a web, Intellectual roperty in cyber space (pp. 155-156, 159). Derwent.

Rodriguez Ruiz, B. (2003). After Napster: Cyberspace and the future of copyright. Computer und Recht International, 1.

The Royal Society of Medicine. (2003). The European copyright directive 2003. Library Information Guides.

Skandamis, N. (1997). European law, institutions and legal orders in the European Union (pp. 433-482), Sakkoulas.

Stamatoudi, I. \& Torremans, P. (2000). Copyright in the new digital environment (Perspectives on intellectual property) (volume 8, pp. 4, 174). Sweet \& Maxwell).

Sterling, J.A.L (2003). World copyright law (chapters 23-24). Sweet \& Maxwell.

Dominic Timms, (2003, 27 October) How the web turned into a mined field. The Guardian.

Tsoukalis, L. (1997). The new European economy revised (pp. 48-49). Oxford University Press. 


\section{Biography}

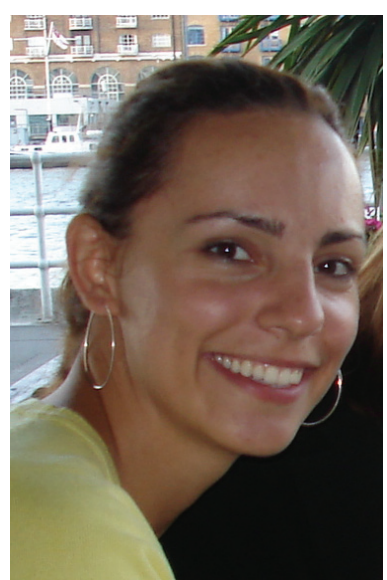

Victoria Banti-Markouti is member of the Athens Bar Association and PhD student of Intellectual Property Law at the Law School of Athens. She holds a bachelors degree in Laws by the University of Athens, a master degree (LLM) in commercial and corporate law by the London School of Economics and a master degree (LLM) in information technology and communications law by the University of Oslo. She has also completed a period of in-service training in the Information Society DG/Service of the European Commission. 